\title{
Cultural Pluralism and Epistemic Injustice
}

\section{Göran Collste}

\section{Linköping University}

\section{Abstract}

For liberalism, values such as respect, reciprocity, and tolerance should frame cultural encounters in multicultural societies. However, it is easy to disregard that power differences and political domination also influence the cultural sphere and the relations between cultural groups. In this essay, I focus on some challenges for cultural pluralism. In relation to Indian political theorist Rajeev Bhargava, I discuss the meaning of cultural domination and epistemic injustice and their historical and moral implications. Bhargava argued that as a consequence of colonialism, "indigenous cultures" were inferiorized, marginalized, and anonymized. Although cultures are often changing due to external influences, I argue that epistemic injustice implies that a culture is forced to subjection, disrespected, and considered as inferior and that it threatens the dominated people's epistemic framework, collective identity, and existential security. Finally, I refer to John Rawls's theory of political liberalism as a constructive approach to avoid parochialism and Western cultural domination.

\section{Keywords}

cultural pluralism; epistemic injustice; liberalism; colonialism; historical justice; globalization; Rajeev Bhargava; John Rawls

\section{Introduction}

For liberalism, values such as respect, reciprocity, and tolerance should frame cultural encounters in multicultural societies. However, it is easy to disregard that power differences and political domination also influence the cultural sphere.

In the age of colonialism, Europe controlled large parts of the world for more than 400 years. In this essay, I discuss cultural pluralism from this historical point of departure. In relation to Indian political theorist Rajeev Bhargava, I discuss the meaning of cultural domination and epistemic injustice and their historical and moral implications. Finally, I refer to John Rawls's theory of political liberalism as a constructive approach to avoid parochialism and Western cultural domination.

\footnotetext{
* Göran Collste, Linköping University, Centre for Applied Ethics, 58183 Linköping, Sweden; Goran. collste@liu.se
} 
Culture is a broad and vague concept. In this essay, culture and cultural differences relate to questions of epistemic frameworks, religions, traditions, and political principles. It could be questionable to use such a broad concept of culture, but it does not pose a problem for my argument.

\section{Epistemic Injustice}

For many years, I was responsible for an international master's program in applied ethics. I taught a course on globalization and global justice, and one aspect was global rectificatory justice: how can we understand global justice from the perspective of historical justice? What are the implications of colonialism for today's global relations? Is the legacy of colonialism still visible? I raised the question whether colonialism had left any morally relevant traces in the present, and a student from Pakistan spoke out and explained with some anger in her voice:

"Yes, certainly! Everything Pakistani is today considered of less worth compared to the West: we consider our own history as shameful and we feel that we are still slaves under the British rulers. These feelings have also a cultural impact today; to be beautiful is to have blond hair, not black, to be civilized is to eat with knife and fork, not to eat in our traditional way, and our traditional languages are superseded by English.”

The student from Pakistan felt that her culture is of less worth than the Western. This experience has its background in the history of colonialism: a history of domination, exploitation, and marginalization.

The problem she points at has several ethical aspects. First, her basic sense of self-respect is violated; second, she does not perceive herself as equal to the "Western"; and third, her autonomy, i.e. her capability to determine her life and destiny, is put in question by her cultural heritage. Hence, the experience of being subject to cultural domination threatens her human dignity, equality, and autonomy.

The story told by the master student illustrates what Rajeev Bhargava calls "epistemic injustice" (Bhargava 2013). Enduring social relations of the superior and subordinate has a tendency to create images of the Other and of oneself, and these images are shared by both the superior and the subordinate. We can notice this phenomenon in the history of class relations, gender relations, race relations, and colonial relations. In the history of colonialism, the master, the white, is looked up to and the servant, the slave, the colored, is someone to look down on. 
Cultural images stamped by colonialism have been analyzed in postcolonial studies (Said 2003, Loomba 2005). I here limit my discussion to Bhargava's ideas of how colonialism implied epistemic injustice.

Colonialism meant occupation of lands and a flow of resources from the colonies to the colonial powers, disempowering the former and enriching the latter. It also presupposed physical violence to keep the subaltern in place. However, colonialism implied more than that. Cultures and minds were also "colonized," according to Bhargava.

When trying to explain and theorize what colonization of cultures and minds means, Bhargava introduced the concept of "epistemic framework." He defined it as follows: "An epistemic framework is a historically generated, collectively sustained system of meanings and significance, by reference to which a group understands and evaluates its individual and collective identity" (Bhargava 2013, 401). An epistemic framework helps us to interpret, understand, and categorize our impressions and experiences, so that they are manageable and possible to communicate and assess. Bhargava's definition also emphasizes the importance of an epistemic framework for identity formation (individual and collective).

A shared epistemic framework is important - indeed necessary - for any social group, such as ethnic, cultural or religious group. It provides basic hermeneutical tools for understanding the world and ourselves. An epistemic framework is also a hermeneutical resource for individuals to interpret and respond to new situations.

According to Bhargava, epistemic injustice means that "concepts and categories" providing self-understanding and orientation are replaced or marginalized by a dominant power, in his case the colonizer. It was, Bhargava wrote, "... important/for the colonizer/to conquer not only the land and goods of the colonized but also their culture and minds" (Bhargava 2013, 414).

How did this materialize? According to Bhargava, cultural and epistemic injustice can take different forms and the epistemic framework of the colonized was overthrown and lost by different processes.

First, one form of epistemic injustice is when the dominant epistemic categories are the ones of the colonizers and the traditional, domestic, historical and cultural traditions become "scattered and diffused." Bhargava wrote, "If the members of a group are denied access to their own culture then they suffer from cultural injustice" (Bhargava 2007, 218). Another form of epistemic injustice implies that the epistemic framework of the colonized is preserved, but it is considered of less worth and is inferior and marginalized in the society. A third form of epistemic injustice implies that the content of 
the colonized epistemic framework is distorted. Bhargava gave an example: For the colonizer, the colonized appeared as a collective, a mass of people and not as individuals. They then transferred this view to the epistemic framework of the colonized, portraying it falsely as "collectivist" (Bhargava 2007, 231). This resulted in colonial policies "... based on the idea that the conception of an individual was simply absent among the colonized and that only group identity mattered in their traditions" (Bhargava 2013, 415). So, in sum, according to Bhargava, epistemic injustice implies that the local epistemic framework is dissolved, marginalized, or distorted.

Why then was it important to conquer the minds of the colonized? It is because, in this way, they overtook views and values of the colonizers. They internalized them, and they then saw themselves as inferior and colonialism as beneficial and fair.

Cultures, epistemic frameworks, and traditions are constantly changing. This is not the problem Bhargava wanted to highlight. No, the moral problem lies in the fact that the "... disapproval stems from the fact that this change is partly orchestrated by an authority with enormous political and economic power ...” (Bhargava 2015, 415). Thus, epistemic injustice was an integrated part of the colonial venture.

Bhargava managed to provide a theoretical explanation of the experience of my master student. However, his texts also raised some questions.

The first question is what exactly his argument refers to. Bhargava argued that as a consequence of colonialism, "indigenous cultures" were inferiorized, marginalized, and anonymized. This is a very general statement. One could question whether his analysis is equally valid for all kinds of cultural manifestations (academic, religious, literary, folkloristic, etc.) or if there are cultural zones that are more or less resilient and then, if there are cultural zones that could resist colonization better than others.

Although the three continents Africa, Asia and Latin America were colonized, they were affected in different ways. For example, in contrast to Africa, India's religious life seems to have been rather unaffected by British colonialism. In English school books for Indian children, Hinduism was represented in a distorted form and the representation was shaped by Christian presuppositions and categories (Balaji 2015). One could even say that Hinduism, as a religion, did not exist before it was so constructed by Western scholars. However still, the religious life of Indians, as well as customs and family life, was rather unaffected by colonialism. In Africa, on the other hand, the indigenous religions were to a large extent superseded by Christianity, although Christianity with an African stain. 
Furthermore, Bhargava argued that “... every group must have access to its own systems of meanings and interpretations ..." and they form "epistemic communities" (Bhargava 2013, 414). Bhargava's theory needs clarifications. First, it is not clear what he means by a "group" and a "community." For Bhargava, the colonization of India led to the epistemic domination of the colonizer and epistemic marginalization of indigenous Indian epistemic frameworks. Although it makes sense to speak of Indian indigenous cultures including not only Hindus but also Sikhs, Muslims, etc. having common ethos, habits, rituals, etc., the precolonial Indian society was also divided into castes, with - possibly - their own epistemic frameworks and forming their own epistemic communities. ${ }^{1}$

Thus, the idea of different epistemic communities does not only refer to different ethnic groups or nations but also to religious and social groups. While an epistemic framework refers to how a group "understands and evaluates its individual and collective identity," it seems that, for example, also socialism, feminism, and Catholicism could be described as epistemic frameworks. This opens up for multiple and overlapping epistemic frameworks; for example, an Indian socialist refers to both an Indian and a socialist epistemic framework and an African Catholic to both an African and a Catholic epistemic framework.

As we noticed, the idea of epistemic injustice presupposes relations of inequality and domination. Drawing on Philip Pettit's analysis of political domination, Amandine Catala introduced the term "hermeneutical monopoly" when a minority in a society is "hermeneutically dominated by a majority." Then, the minority lacks the resources to raise their voices in the public discourse and their views are dismissed by the majority (Catala 2015, 430). Hence, epistemic domination is one form of domination in parallel to other forms, such as economic and political. However, when Catala spoke of cultural and ethnical minorities in Western countries, Bhargava spoke of dominated majorities in colonized nations.

Second, the idea that each group has its own "... system of meanings and interpretations ...” could be interpreted as implying a kind of relativism, because if each group has its own epistemic framework, it is difficult to see how they could communicate with each other: We know the world from our epistemic framework and you from yours and there is no way your interpretation could challenge ours. Without doubt, such a view would have some very problematic epistemic implications.

However, Bhargava did not adhere to relativism because he also argued for the possibility of "biculturalism," which means a "potentially common tradition." Yes, he even foresaw "... the renewal of western traditions by non-western

1 See Fricker (2007) and Catala (2015) for analyses of epistemic dominations within societies. 
people ..." (Bhargava 2013, 416-417). Hence, epistemic frameworks differ and overlap and communication is possible. In fact, there are reasons to believe that the Indian and Western traditions can co-exist and even integrate. Liberal ideas inspired the leaders of the new nation after independence from Britain, in particular Nehru who said "I am the last Englishman to rule in India."

\section{Progress and Cultural Change}

Bhargava argued that colonialism implied that local cultures were marginalized. But are not cultures normally in a state of constant change? When we look at history, we find many examples of how one culture has been superseded by another. Is that always something to regret? Perhaps, the new culture is preferable? Was it for example a misfortune that Christianity superseded the Roman religion in the first centuriesy AD or that Islam superseded the Arabic religions in the sixth to seventh centuries? What was lost and what was gained? Did perhaps the new religion and culture offer an enhanced collective identity and existential security compared to the old ones? In line with Charles Taylor, one could presume that cultures have intrinsic value. He wrote: "... it is reasonable to suppose that cultures that have provided the horizon of meaning for large numbers of human beings, of diverse characters and temperaments, over a long period of time - that have, in other words, articulated their sense of the good, the holy, the admirable - are almost certain to have something that deserves our admiration and respect, even if it is accompanied by much that we have to abhor and reject." (Taylor 1994, 72-73). On the other hand, even if we acknowledge the intrinsic value of cultures, it does not necessarily mean that all cultures have equal value. Brian Barry wrote: "... some cultures ... are better than others: more just, more free, more enlightened, and generally better adapted to human flourishing" (Barry 2001, 267). So, following Taylor, cultures are valuable because they provide "horizons of meaning," but - as Barry argued - some are more valuable than others due to their capacity to make humans flourish.

So, what is then morally wrong with epistemic injustice? Let me suggest the following answer. Epistemic injustice

1. implies that a culture is forced to subjection;

2. implies that the dominated culture is disrespected and considered as inferior;

3. implies a threat to the dominated people's epistemic framework, collective identity, and existential security; and

4. implies an enduring sense of inferiority among the adherents of the old culture. 
So, epistemic injustice implies force and subjection. If a culture is valuable while it provides its adherents with instruments to interpret, understand, and provide meaning to their existence and, also in Taylor's terms, articulate a sense of the good and holy, epistemic injustice is also morally wrong while it means an infringement of these valuable instruments and states of mind.

Given that Bhargava's description of the colonization of epistemic frameworks is correct, the indigenous cultures were dominated by force and were considered inferior, and the consequences were a loss of collective identity and a sense of existential insecurity among the colonized people. This sense of inferiority is enduring. Hence, the moral problem with epistemic injustice in the wake of colonialism is that it implied an enduring dominance and a sense of inferiority among the subaltern.

\section{Globalization and Epistemic Injustice}

Is then epistemic injustice in Bhargava's sense a phenomenon of the colonial past - although with enduring consequences?

Today, we live in an age traced by globalization. The meaning and impact of globalization are much discussed, and I will only focus on some aspects. To the present, globalization is not characterized by equality and reciprocity. Many facets of globalization mean the dominance of powerful economic organizations and multinational companies and a Westernization or Americanization of cultures and values. From this perspective, globalization implies neocolonization of cultures and minds.

Globalization implies epistemic injustice in various forms, and I will distinguish between an apparent and a subtle form. The apparent form is illustrated by the global implementation of intellectual property rights, which is an example of globalization of parochial Western values at the expense of local and indigenous. Let me explain with the help of an example.

One feature of the last decades' globalization is the global commercialization of all sorts of goods, including medicines, herbs, and seeds. This was manifested by the so-called Agreement on Trade-Related Aspects of Intellectual Property Rights (TRIPS) agreement in 1994. According to the TRIPS agreement, intellectual property such as medicines and genetic material should be protected globally, and the TRIPS agreement was institutionalized when ratification of TRIPS became a condition for membership of the World Trade Organization (WTO).

One of the controversial aspects of the global intellectual property regime is the extension of property rights to cover also traditional knowledge In a 
number of cases, plants and herbs used for ages by traditional communities and indigenous peoples have been patented by Western firms. Here, traditional knowledge and communal ownership come into conflict with privatization and property rights. This value conflict is an example of when globalization means the domination of Western values at the expense of the values of weaker and more vulnerable communities and people (Shiva 2001, Commission 2002, Anderson 2015).

Through the many ways that Western ideals are permeating the world through adverts, news media, and Hollywood films, globalization also implies a subtler form of cultural injustice. Here, the Western ideals of beauty, life style, and consumption are becoming global norms, which on the receiving side of the globe may lead to a contempt for one's own culture and tradition. As a consequence, many women in Africa and Asia are whitening their skin and straightening their hair to live up to the Western ideals of beauty. According to a report from the University of Cape Town, 77\% of women in Nigeria and 35\% of women in South Africa use skin lighteners (http://www.bbc.com/ news/world-africa-20444798).

So, what then are the remedies for epistemic injustice in the past and how can we avoid that also globalization will imply epistemic injustice?

First and probably most important is that intellectuals in the countries who are subjects of epistemic injustice rediscover their own intellectual and epistemic traditions. This is also Bhargava's strategy. In his ambition to rediscover the Indian tradition in political theory, he studied the edicts of the progressive Emperor Asoka from the third century BC. Similarly, African philosophers are developing the idea of Ubuntu, which expresses deep values of community in the African tradition (Metz and Gaie 2010).

When commenting on the discussion of global justice, the Indian theorist Aakash Singh wrote:

"[...] as the global justice debate amplifies unreflexively this increasingly discredited tendency of the wider social sciences to favour the epistemology and centrality of Anglo-American political theory/ theorists, generally excluding non-western voices from participation. Here, the term 'global' seems to signify outward expansion from the center; our attempt to extend our conception/demands of justice to them. Many non-western scholars, therefore, see the global justice debate as a recapitulation of the characteristic practices and attitudes of colonial liberalism" (Aakash 2014).

What can we who are ancestors of the colonizers and who represent the global rich do today? How can we avoid "one-directional" communication, and how 
can we avoid epistemic injustice in the wake of globalization? As philosophers, Nancy Fraser and Axel Honneth have emphasized, "recognition" is a central concept here. Fraser wrote, "Misrecognition ... means social subordination in the sense of being prevented from participating as a peer in social life" (Fraser 2001, p.24). Misrecognition seems to be one condition for epistemic injustice. Hence, the social subordination of the Other could be overcome by recognition, i.e. to ensure that everyone has an equal say in conversations and dialogs.

Listening to the Other follows from recognition. To listen is more than to hear. Michael Purdy defined listening as "... the active and dynamic process of attending, perceiving, interpreting, remembering, and responding to the expressed (verbal and nonverbal) needs, concerns, and information offered by other human beings" (Purdy 1991). Listening is a crucial condition for communication and a requirement for reciprocity, i.e. for "fair terms of cooperation” to quote Rawls (Rawls 1993, 16).

\section{Avoiding Parochialism}

As Aakash reminds us, in order to remedy for the colonial past and avoid epistemic injustice in the present, we have to reconsider the way we philosophize about global justice and international relations. In The Law of Peoples (1999), which is a treaty on international relations and justice, John Rawls took much efforts in developing a theory characterized by non-parochialism, meaning that the theory should avoid cultural biases and one-sidedness and instead accept pluralism and respect different traditions of how a society is formed.

Already in his work Political Liberalism from 1993, Rawls distanced himself from a view of justice that universalizes western liberal values. He admits that his own theory of justice from 1971 suffers from this limitation. For example, the principle of moral autonomy developed in $A$ Theory of Justice "... fails to satisfy the criterion of reciprocity required of reasonable political principles ..." (Rawls 1996, xlv). As an alternative, in Political Liberalism, he developed a theory of reasonable pluralism and justification of a political conception of justice based on an "overlapping consensus" of different - what he called "comprehensive doctrines," and comprehensive liberalism is one of them (ibid xlii). This implies that basic political institutions and rights are justified by all reasonable doctrines, although the reasons will differ between different doctrines.

In Political Liberalism, Rawls's aim was to develop criteria of justification of a theory of justice in plural societies. The aim of The Law of Peoples (1999) was to develop a theory of international relations in a plural world, and Rawls 
raises the question how to achieve an inclusive Society of Peoples, i.e. a global community of peoples who cooperate and live peacefully together.

According to Rawls, not only liberal peoples but also - what he called - "decent hierarchical peoples" are full members of the Society of Peoples. He takes the conceived Islamic people Kazanistan as his case in point. Islam is the favored religion, and only Muslims can have governmental positions. Other religions are tolerated, and their believers have civic rights. They are also included in a "decent consultation hierarchy," and they are able to influence the political decisions from this position (Rawls 1999, 75-77). However, Kazanistan deviates in important respects from liberal ideals.

The contrast between a cosmopolitan, liberal global order and the Society of Peoples that Rawls favors became clear when Rawls discussed human rights. In The Law of Peoples, Rawls only included "urgent human rights," i.e. freedom from slavery, liberty of conscience and security of ethnic groups from mass murder and genocide. However, he did not include equal individual rights or liberal democracy (ibid, 78-81). The reason as he explained it is that "Human rights, as thus understood, cannot be rejected as peculiarly liberal or special to the Western tradition. They are not politically parochial" (ibid, 65).

Rawls's theory has been the target of critique by some liberals. Why, they ask, should we be satisfied with anything less than a society that implements full and universal human rights, and why should we in the long run tolerate political systems that are hierarchical and that distinguish between different ethnical and religious groups with respect to rights of influence? Why should non-Muslim citizens in Kazanistan accept the role as secondary members of their society? (Li 1995, Nickel 2006) These critical questions are indeed challenging.

On the other hand, with Bhargava's critique of epistemic injustice in mind, there are good reasons for Rawls's position. In view of the history of colonialism - and the present globalization - we should be more cautious to assume that Western values, Western political systems, and Western political principles are universally valid and applicable. We must acknowledge that there are other political cultures and traditions that are acceptable and worthy of respect. Following Rawls, this acceptance of different political traditions does not mean that liberals should abstain from working for extension of human rights in any society they live in; only that liberalism is not a necessary requirement for inclusion in the Society of Peoples, the global community.

This does not imply that a wider conception of human rights necessarily mirrors a Western or liberal comprehensive doctrine. The main human rights treaties have been ratified by a large majority of the nations of the world, and 
as a German philosopher Heiner Bielefeldt remarked, human rights can be understood "... as the centre of a cross-cultural 'overlapping consensus' on basic normative standards in our increasingly multi-cultural societies." No, what Rawls's proposal might avoid is a "... cultural essentialist occupation" of human rights (Bielefeldt 2016, 86).

Should we then accept this more limited human rights conception as the ground for a Society of Peoples or should we assume a broader liberal conception of human rights? It is not an easy choice. However, it seems to me that Rawls's position avoids that faults of the past are repeated in the present. We should bear in mind that Rawls does not accept any kind of hierarchical societies. They have to live up to the conditions of respecting urgent human rights, i.e. respect for human beings' freedom of thought and organization and their right to influence the government (although in different ways and perhaps within different institutions).

\section{Conclusion}

The aim of this essay was to discuss the meaning of epistemic and cultural injustice and how to overcome it in the present age characterized by globalization and the encounter of different cultures.

The history of colonialism is a history of enduring cultural domination and epistemic injustice. Epistemic injustice is prima facie problematic from a moral point of view, while it implies domination, disrespect, a sense of inferiority and erosion of dominated people's epistemic framework, collective identity, and existential security.

Today's possibilities of cultural encounters and emerging multicultural societies offer a potential for learning, cultural enrichment and plurality. However, the realization of this potential presupposes that we recognize the others and listen to their beliefs and values. As Rawls showed, avoiding parochialism is both necessary and possible in present plural societies.

\section{References}

Anderson, Jane.2015. Indigenous Knowledge and Intellectual Property Rights. International Encyclopedia of the Social \& Behavioral Sciences, 2nd edition, Volume 11, Elsevier. pp 769779.

Balaji, Murali. 2018. "The Colonized Mind. Thoughts on colonialism, Christianity and the relinquishment of Hindu consciousness.” Hinduism Today. https://www.hinduismtoday. $\mathrm{com} /$ modules/smartsection/item.php?itemid=3103.

Barry, Brian. 2002. Culture and Equality. An Egalitarian Critique of Multiculturalism. Harvard: Harvard University Press. 


\section{Cultural Pluralism and Epistemic Injustice}

Bhargava, Rajeev. 2007. "How Should We Respond to the Cultural Injustices of Colonialism?” In Reparations: Interdisciplinary Inquiries, edited by J. Miller and R. Kumar. Oxford: Oxford University Press.

Bhargava, Rajeev. 2013. “Overcoming the Epistemic Injustice of Colonialism.” Global Policy 4 (4): 413-417.

Bielefeldt, Heiner. 2016. “'Western' versus 'Islamic' Human Rights Conceptions? A Critique of Cultural Essentialism in the Discussion on Human Rights," In Ethics and Communication. Global Perspectives, edited by G. Collste. London: Rowman \& Littlefield International.

Catala, Amandine. 2015. "Democracy, Trust, and Epistemic Injustice." The Monist, 98 (4): 424-440.

Collste, Göran. 2015. Global Rectificatory Justice. Basingstoke: Palgrave.

Fricker, Miranda. 2007. Epistemic Injustice: Power and the Ethics of Knowing. Oxford: Oxford University Press

Kymlicka, Will. 1996. Multicultural Citizenship A Liberal Theory of Minority Rights. Oxford: Oxford University Press

Metz, Thaddeus and Gaie Joseph, B. R. 2010. "The African Ethic of Ubuntu/Botho: Implications for Research on Morality." Journal of Moral Education 39 (3): 273-290.

Nickel, James. 2006. “Are Human Rights Mainly implemented by Intervention?” In Rawls's Law of Peoples. A Realistic Utopia?, edited by R. Martin and D. Reidy. Oxford: Blackwell Publishing.

Rawls, John. 1996. Political Liberalism. New York: Columbia University Press.

Rawls, John. 1999. The Law of Peoples. Cambridge: Harvard University Press.

Sen, Amartya. 1999. Development as Freedom. Oxford: Oxford University Press.

Singh, Aakash. 2013. "Deparochializing the Global Justice Debate, Starting with Indian Political Theory." Global Policy 4 (4): 418-419

Li, Xiarong. 1995. “A Critique of Rawls's Freestanding Justice.” Journal of Applied Philosophy, 12 (3): 263-271.

Taylor, Charles. 1994. “The Politics of Recognition.” In Multiculturalism: Examining the Politics of Recognition, edited by Amy Gutman. Princeton: Princeton University Press. 